\title{
Pelatihan Digital Marketing untuk Produk Wirausaha Mahasiswa Masa Pandemi Covid-19
}

\author{
Andy Arya Maulana Wijaya ${ }^{1 *}$, L.M Azhar Sa'ban ${ }^{2}$, Anwar Sadat $^{3}$, Nastia ${ }^{4}$, Wd. Riniati ${ }^{5}$ \\ 1,2,3,4Fakultas IImu Sosial dan IImu Politik, Universitas Muhammadiyah Buton, Jalan \\ Betoambari No. 36, Batupoara, Betoambari, Kota Baubau, Sulawesi Tenggara \\ 93712. Telp : (0402) 2827038, bulawambona.87@gmail.com, izharrazi@gmail.com, \\ anwarsadat685@gmail.com, nastia567@gmail.com \\ ${ }^{5}$ Fakultas Keguruan dan IImu Pendidikan, Universitas Muhammadiyah Buton, Jalan \\ Betoambari No. 36, Batupoara, Betoambari, Kota Baubau, Sulawesi Tenggara \\ 93712. Telp : (0402) 2827038, riniatiwaode@gmail.com
}

*Korespondensi: bulawambona.87@gmail.com

Diterima: 13 September 2021 ; Review: 22 Oktober 2021 ; Disetujui: 26 Desember 2021 ; Diterbitkan: 31 Desember 2021

\begin{abstract}
Abstact
Baubau City in the future need for labor is more competitive, estimating the growth of the need for employment and the workforce in the next few years has implications for the need for creative innovation to be able to work. This community service activity aims to provide education for business actors at the University Muhammadiyah Buton. The method of carrying out activities using socialization and FGD to students with a digital marketing approach, external activities directed at creating content uploaded on YouTube to be disseminated. The result of the activation process is that student business actors have practiced digital marketing patterns, mainly through social media posts, but in content management and display are not optimal. With the implementation of digital marketing training, business students can optimize social media for marketing, create easy-toremember account names, post regularly and regularly, use hashtags, as well as active social media interactions to better respond to consumen. In addition, training assignments are carried out through the creation of video content and have been uploaded via YouTube.
\end{abstract}

Keywords : Training, digital marketing, entrepreneurship, student

\begin{abstract}
Abstrak
Kebutuhan tenaga kerja di Kota Baubau semakin kompetitif, proyeksi pertumbuhan kebutuhan lapangan kerja dan angkatan kerja beberapa tahun kedepan berimplikasi perlu inovasi kreatif untuk bisa bekerja. Kegiatan pengabdian masyarakat ini bertujuan untuk memberikan edukasi bagi para pelaku usaha mahasiswa Universitas Muhammadiyah Buton. Metode pelaksanaan kegiatan dengan menggunakan sosialisasi dan FGD kepada para mahasiswa dengan pendekatan digital marketing, luaran kegiatan peserta diarahkan untuk dapat membuat konten yang diupload dalam youtube untuk dapat disebarluaskan. Hasil proses kegiatan bahwa pelaku usaha mahasiswa sudah mempraktikan pola digital marketing utamanya melalui postingan media sosial, namun dalam manajemen konten dan tampilan belum optimal. Dengan pelaksanaan pelatihan digital marketing mahasiswa pelaku usaha dapat mengoptimalkan media sosial untuk pemasaran, membuat nama akun yang mudah diingat, postingan yang berkala dan rutin, penggunaan hastag serta interaksi media sosial yang aktif guna merespon pembeli dengan lebih baik. Selain itu, penugasan pelatihan dilakukan melalui pembuatan video konten dan telah di upload melalui youtube.
\end{abstract}

Kata Kunci : Pelatihan, digital marketing, wirausaha, mahasiswa 


\section{PENDAHULUAN}

Dinamika kebutuhan tenaga kerja semakin kompetitif. Dibutuhkan inovasi dan kreatifitas untuk dapat memberikan jawaban terhadap kondisi kebutuhan tenaga kerja dan lapangan pekerjaan yang tersedia. Kewirausahaan menjadi salah satu solusi dalam membuka lapangan kerja yang lebih luas. Namun berwirausaha juga membutuhkan inovasi dan pemanfaatan teknologi informasi yang kini dikenal dengan digital marketing.

Digital marketing merupakan sebuah istilah yang sedang populer belakangan ini. Dengan memanfaatkan kemajuan teknologi komunikasi, seseorang dapat memasarkan produknya melalui jaringan internet. Dari data mengenai aktivitas internet ini, bahwa pengguna internet di Indonesia tercatat 175,4 Juta orang dengan pengguna aktif pada jaringan media sosial sebesar 160 juta orang. Disisi lain, pertumbuhan pengguna sosial media di Indonesia pada Januari 2019 hingga Januari 2020 sebesar 12 Juta Pengguna.

Hal ini juga terjadi di Kota Baubau, khususnya di kalangan mahasiswa yang memiliki usaha sebagai sumber penghasilannya. Universitas Muhammadiyah Buton juga memiliki perhatian khusus pada usaha wirausaha mahasiswa, sehingga dapat menjadi keterampilan masa depan dan bukan saja sebagai sampingan bagi mahasiswa. Dari penelusuran yang dilakukan melalui kegiatan ini, diperoleh sejumlah usaha mahasiswa yang berorientasi pada platform online.

Pelatihan digital marketing dibutuhkan untuk dapat memberikan keterampilan khusus pada mahasiswa, sehingga dapat mengelola usahanya sebagai sumber kehidupan dan jaminan masa depannya. Menumbuhkan jiwa berwirausaha pada mahasiswa juga akan mengurangi tingkat pengangguran serta sebagai orientasi masa depan ketika mereka telah menyelesaikan kuliahnya, karena setelah lulus dari perkuliahan diharapkan mahasiswa mampu mengembangkan usahanya dengan memanfaatkan perkembangan teknologi informasi (Wijoyo et al., 2020).

Menghadapi kenyataan diatas, kegiatan ini merupakan luaran perkuliahan kewirausahaan dan salah satu bagian dari program kerja lembaga kemahasiswaan diharapkan dapat mengembangakan kompetensi mahasiswa dan lulusan dalam berwirausaha. Dengan pelatihan pelatihan digital marketing diharapkan mampu meningkatkan jumlah wirausaha serta konten usaha yang lebih berorientasi pada digitalisasi. Sehingga, mahasiswa lebih mandiri dalam usaha serta mandiri dalam gagasan usaha guna menghadapi para pesaing di masa depan.

\section{ANALISIS SITUASI}

Sejumlah mahasiswa di Universitas Muhammadiyah Buton bergerak pada usaha rumahan untuk membantu pembiayaan kuliahnya. Dalam penelusuran usaha mahasiswa yang cukup aktif di media sosial didapati sekitar 16 usaha mahasiswa. Pemasaran yang dilakukannya beragam, dengan memanfaatkan media sosial untuk memasarkan produk usaha mereka. Hanya saja dalam amatan awal, proses pemasaran dengan menggunakan media sosial ini sejalan dengan konsep digital marketing, hanya saja belum optimal untuk dimanfaatkan sebagaimana indiktor digital marketing. Hal ini disebabkan oleh karena penggunaan teknologi informasi belum ditunjang dengan kompetensi dalam memanfaatkan fitur yang ada pada teknologi tersebut (Hanief et al., 2020).

Salah satunya adalah menggunakan digital marketing, dimana selain pemasaran yang menggunakan media online namun juga perlu diperkuat dengan konten, narasi yang tepat, hingga model foto produk yang eyecatching sehingga mampu menarik minat konsumen hanya dari saat melihat postingan produk saja. Dari data yang dihimpun perihal jumlah jenis usaha mahasiswa, yakni terdapat 15 Jenis usaha yang terbagi pada beragam bentuk mulai dari jajanan, aksesoris hingga kosmetik alami.

Dalam pembelajaran kewirausahaan memang diperkenalkan hal tersebut, namun belum spesifik untuk dapat memberikan optimalisasi digital marketing secara profesional. Mulai dari narasi yang masih kurang memberikan afirmasi positif atas produk, hingga cara pengambilan gambar yang optimal dalam menampilkan produk. Potensi pengembangan 
wirausaha mahasiswa cukup besar dan sebagai peluang membuka lapangan pekerjaan bagi mahasiswa yang berbasis inovasi dan kreatifitas.

Mitra dalam pengabdian masyarakat ini adalah kelompok mahasiswa wirausaha yang berhimpun dalam lembaga kemahasiswaan. Dalam hal ini adalah Ikatan Mahasiswa IImu Pemerintahan (IMPRESIP) FISIP UM Buton yang dipimpin oleh Ahmad Muhardin Hadmar sebagai ketua.

Pada gambar 1, nampak bahwa cara pengambilan gambar produk usaha oleh mahasiswa belum memiliki kaidah yang cukup untuk mendukung pemasaran yang baik. Gambar masih buram, angel gambar yang sembarang, hingga kualitas gambar yang tidak begitu jelas memberikan pengaruh secara visual kepada pembeli.
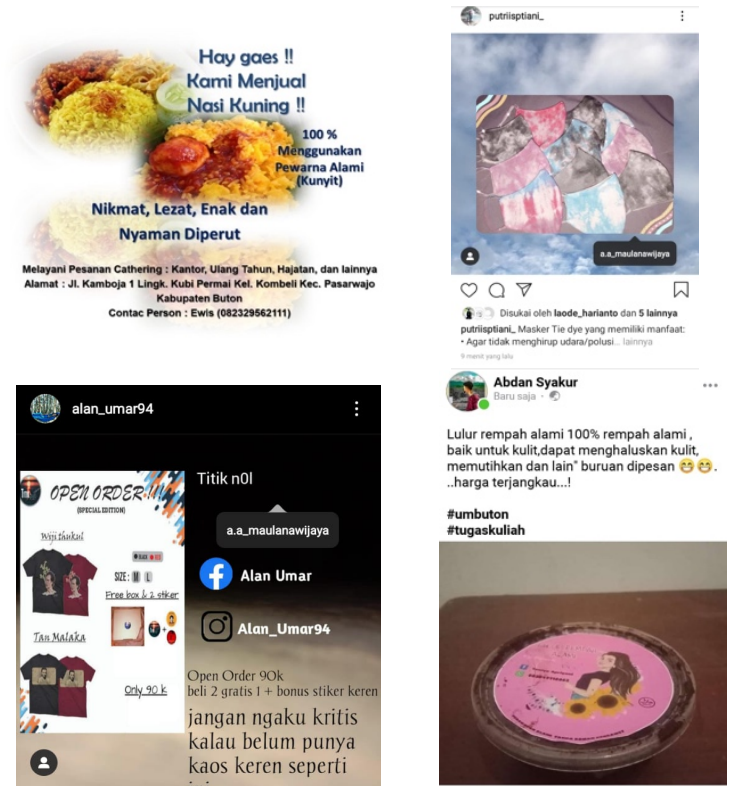

Sumber : Hasil Pelaksanaan (2021)

Gambar 1. Contoh tampilan awal postingan produk wirausaha mahasiswa

Selain itu, nampak bahwa kekuatan narasi produk untuk mendukung digital marketing belum cukup kuat memberikan afirmasi terhadap produk. Hal ini justru akhirnya menutupi potensi produk yang sudah cukup baik. Dari penggambaran situasi produk usaha mahasiswa yang telah di-share tersebut, sejatinya konten digital marketing yang diusung pada konsep pemasaran online, belum mampu memberikan kekuatan produk dan target pasar yang dituju bagi produk yang dijualkan oleh masyarakat. Digital marketing dalam hal ini dipercaya sebagai pemberdayaan kelompok usaha (Azizah, 2019), Peningkatan perekonomian (Pranoto et al., 2019), untuk kesejahteraan kelompok usaha (Pranadji, 2016), bahkan pada beberapa kasus Digital marketing memiliki andil yang cukup positif dalam pengembangan usaha kecil dan menengah (Purwana et al., 2017; Yusmedi Nurfaizal \& Toni Anwar, 2019).

Program pengabdian kepada masyarakat ini ditujukan untuk dapat memberikan tambahan pengetahuan bagi mahasiswa yang memiliki produk usaha dalam hal penggunaan digital marketing untuk mendukung pengembangan usaha mereka, serta menjalankan fungsi promosi, diperlukan pencerdasan penggunaan media praktis seperti template dan teknis perancangan komunikasi berbasis visual. Sejalan dengan itu, pembahasan perihal inovasi ini juga dikemukakan oleh (Adi et al., 2021), yang menganggap bahwa banyak UMKM yang belum mengetahui tentang pentingnya strategi kampanye dan estetika dalam mengkomunikasikan produknya. Untuk mendorong kemandirian UMKM dalam menjalankan fungsi promosi, diperlukan pencerdasan penggunaan media praktis seperti template dan teknis perancangan komunikasi berbasis visual. 
Selain itu, program kegiatan ini juga dilakukan workshop dan evaluasi terhadap workshop yang telah dilakukan guna melihat perkembangan pemahaman terkait penggunaan digital marketing dikalangan usaha mahasiswa.

Dari analisis situasi yang dideskripsikan diatas, dapat digambarkan bahwa permasalahan mitra dalam usulan program pengabdian masyarakat ini digambarkan dalam 3 pikiran pokok utama sebagai pengembangan pemasaran produk usaha melalui penggunaan digital marketing, yaitu sebagai berikut:

a. Belum optimalnya keterampilan mitra dalam teknik pengambilan gambar produk, pencahayaan, serta angle foto yang baik secara visual dalam pemasaran produk.

b. Masih lemahnya kemampuan mitra dalam memberikan narasi atau deskripsi produk yang digunakan untuk menggambarkan kualitas dan keunggulan produk usahanya.

c. Lemahnya kemampuan conten creator mitra sebagai sarana promosi produk dalam kaidah digital marketing yang optimal.

Berdasarkan kondisi diatas, maka pengabdian masyarakat ini dilakukan dengan tujuan untuk memberikan pelatihan praktis digital marketing bagi mempromosikan produk wirausaha mahasiswa, menjadi lebih ramah visual dan memiliki kemampuan untuk membuat narasi menarik bagi promosi produknya tersebut.

\section{METODE PELAKSANAAN}

Metode pelaksanaan program pengabdian kepada masyarakat ini disusun melalui penjadwalan yang disesuaikan dengan relevansi masing-masing tahap terhadap solusi yang ditawarkan. Adapun metode pelaksanaan pengabdian kepada masyarakat ini dilakukan menurut alur tabel dibawah ini;

Tabel 1. Proyeksi Tahapan Pelaksanaan Program Pengabdian Masyarakat

\begin{tabular}{|c|c|c|c|c|}
\hline No. & Nama Kegiatan & $\begin{array}{c}\text { Format } \\
\text { Kegiatan }\end{array}$ & Deskripsi Program & $\begin{array}{l}\text { Kompetensi } \\
\text { yang } \\
\text { Diharapkan }\end{array}$ \\
\hline 1. & $\begin{array}{l}\text { Penjelasan } \\
\text { Umum Digital } \\
\text { Marketing }\end{array}$ & $\begin{array}{l}\text { Kuliah } \\
\text { Umum }\end{array}$ & $\begin{array}{l}\text { Deskripsi mengenai } \\
\text { keunggulan dan potensi } \\
\text { penggunaan digital marketing } \\
\text { bagi kalangan wirausaha } \\
\text { mahasiswa }\end{array}$ & $\begin{array}{l}\text { Peningkatan } \\
\text { kompetensi } \\
\text { dalam } \\
\text { kemampuan } \\
\text { Digital } \\
\text { Marketing }\end{array}$ \\
\hline 2. & $\begin{array}{l}\text { Sarana atau } \\
\text { Alat dalam } \\
\text { menggunakan } \\
\text { Digital } \\
\text { Marketing }\end{array}$ & Workshop & $\begin{array}{l}\text { Pengenalan terhadap potensi } \\
\text { media sosial }\end{array}$ & $\begin{array}{l}\text { Pemilihan } \\
\text { Media Sosial } \\
\text { yang relevan } \\
\text { sama } \\
\text { pemasaran } \\
\text { produk dan } \\
\text { pelanggan }\end{array}$ \\
\hline 3. & $\begin{array}{l}\text { Conten Creator } \\
\text { terhadap produk }\end{array}$ & Workshop & $\begin{array}{l}\text { Dasar-dasar penulisan untuk } \\
\text { pemasaran, Teknik Fotografi } \\
\text { produk yang mudah, Editing } \\
\text { Foto. }\end{array}$ & $\begin{array}{l}\text { Kemampuan } \\
\text { display produk } \\
\text { yang } \\
\text { profesional. }\end{array}$ \\
\hline 4. & $\begin{array}{l}\text { Penugasan } \\
\text { Konten Kreatif }\end{array}$ & $\begin{array}{l}\text { Pembuatan } \\
\text { Video }\end{array}$ & $\begin{array}{l}\text { Membuat video untuk } \\
\text { mempromosikan usaha } \\
\text { dengan tahap-tahap yang } \\
\text { telah diberikan saat workshop. }\end{array}$ & $\begin{array}{l}\text { Mengupload } \\
\text { video yang telah } \\
\text { dibuat di upload } \\
\text { ke youtube. }\end{array}$ \\
\hline
\end{tabular}

\section{HASIL DAN PEMBAHASAN}

Program pelatihan digital marketing ini dilakukan dengan harapan adanya pemahaman konsep dan aplikasi digital marketing untuk mendukung wirausaha mahasiswa di Universitas Muhammadiyah Buton. Peserta kegiatan ini adalah mahasiswa yang memiliki usaha, program terbuka untuk umum namun dengan jumlah yang terbatas 
karena pada beberapa sesi mensyaratkan untuk pertemuan langsung, sedangkan pandemi covid-19 masih membatasi aktivitas yang dilakukan secara langsung.

Setelah proses sosialisasi program kepada mahasiswa, maka peserta kegiatan ini adalah 18 orang dari 22 orang yang ditargetkan. Kegiatan berlangsung selama satu hari untuk kuliah umum dan workshop untuk memahami digital marketing dan kompetensi untuk dapat memproduksi konten sederhana bagi promosi produk usaha mahasiswa. Selanjutnya, akhir pelatihan ini akan memberikan tugas untuk peserta membuat konten video sederhana menggunakan alat yang juga sedehana melalui handphone, dalam mempromosikan salah satu produk wirausaha mahasiswa.

\subsection{Profil Usaha Peserta Pelatihan}

Profil peserta dilakukan melalui penelusuran awal pada kuisioner yang dibagikan kepada peserta kegiatan saat registrasi, diperoleh bahwa $100 \%$ peserta telah menyebarluaskan foto produk mereka di media sosial yaitu Facebook dan Instagram, sebagai sarana marketing produknya. Namun, setelah diperoleh hasil pada pertanyaan lanjutan mengenai produksi konten yang mereka lakukan diperoleh hasil sebagaimana yang ditampilkan pada tabel berikut ini;

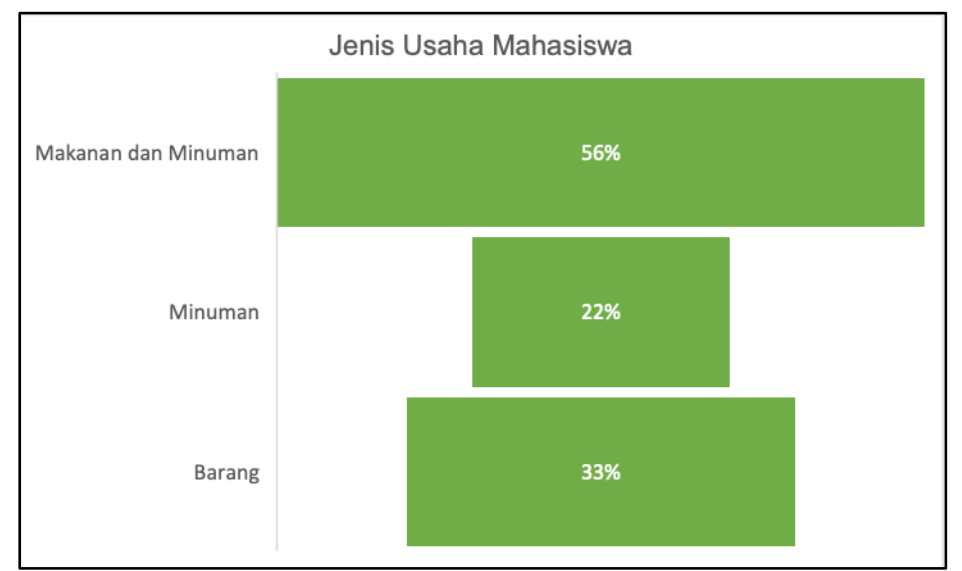

Sumber : Hasil Pelaksanaan (2021)

Gambar 2. Jenis Usaha Mahasiswa (Peserta Pelatihan)

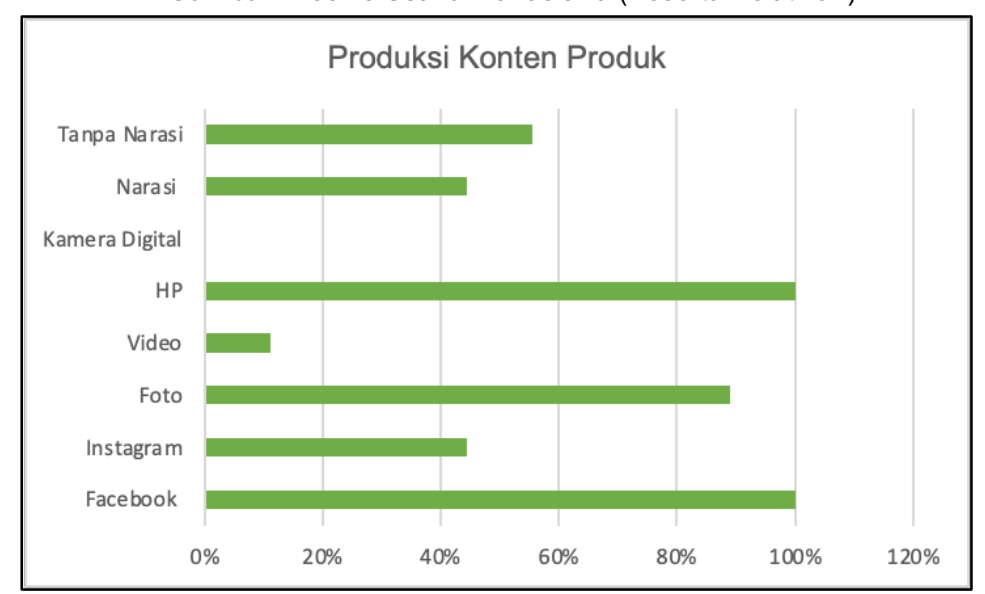

Sumber : Hasil Pelaksanaan (2021)

Gambar 3. Produksi Konten Produk Peserta Pelatihan

Dari gambar 2, dapat dijelaskan bahwa jenis usaha makanan dan minuman adalah jenis usaha terbanyak dari peserta yang mengikuti pelatihan digital marketing (56\%). Sedangkan Facebook menjadi media paling banyak digunakan oleh peserta dalam memasarkan produknya (100\%), konten diproduksi melalui handphone (HP) dan disajikan melalui foto produk, namun produk diakui belum sepenuhnya ditunjang dengan narasi yang mendukung konten produk usaha peserta pelatihan (56\%). Dari penggambaran tersebut 
dapat disimpulkan bahwa peserta kegiatan pelatihan, membutuhkan penguatan kompetensi dalam menghasilkan konten digital marketing bagi usaha mereka. Dari hasil evaluasi aktivitas usaha peserta juga diperoleh data sebagai berikut :

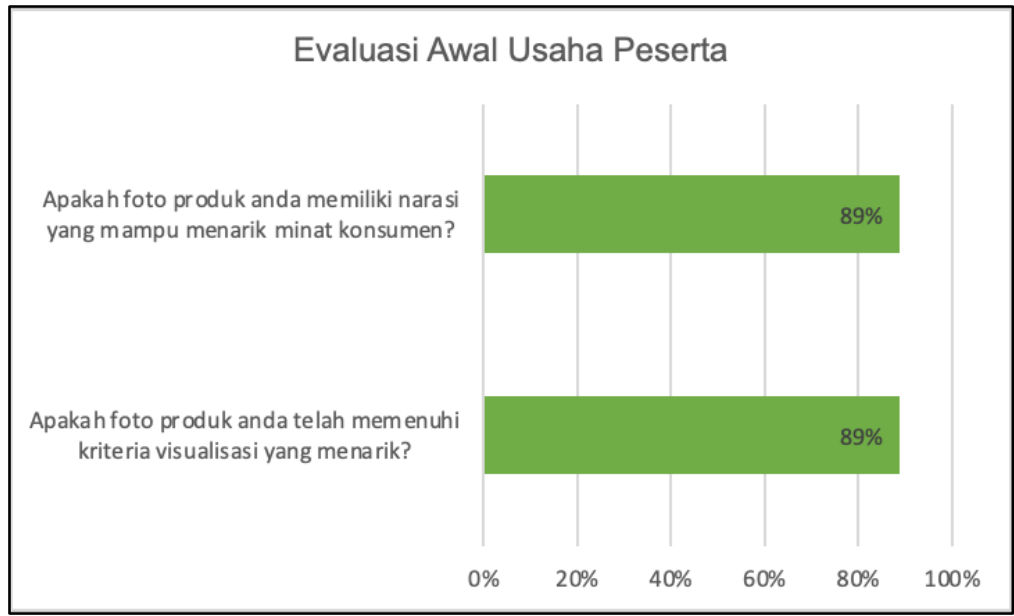

Sumber : Hasil Pelaksanaan (2021)

Gambar 4. Evaluasi Awal Usaha Peserta

Dengan pengisian quisioner ini kemudian menjadi pembahasan pembuka workshop yang dilakukan, sehingga dapat dimanfaatkan dalam merumuskan dan mendiskusikan luaran workshop yang dilakukan. Workshop diawali dengan pemberian materi mengenai digital marketing; peluang dan tantangannya bagi wirausaha mahasiswa, apalagi hal ini berkenaan dengan situasi pandemi covid 19 yang memungkinkan bagi ekpansi produk usaha melalui jejaring media sosial yang dimilikinya.

Setelah itu, dari evaluasi awal sebagaimana yang ada pada gambar 4 memberikan gambaran bahwasanya peserta mengakui postingan produk yang mereka lakukan di media sosial, belum maksimal ditunjang dengan foto produk yang baik serta narasi yang mampu membangun hubungan atau ketertarikan bagi konsumen terhadap produk mereka. Selain itu, mereka belum berani untuk mencoba menggunakan aplikasi online seperti canva untuk mempercantik tampilan produknya, karena kurang paham dengan cara pembuatan konten serta penggunaan media sebagai sarana marketing.

\subsection{Workshop Digital Marketing}

Pelatihan ini menyadari bahwa model pelatihan harus sejalan dengan perkembangan teknologi komunikasi dan informasi. Dengan begitu, peserta dapat memperoleh pengetahuan dalam menghasilkan konten produk yang lebih optimal dalam menunjang usaha mereka untuk menjadi wirausaha yang mandiri dan sukses. Pelatihan ini menggunakan dua metode yakni cemarah yang diselingi dengan diskusi, selanjutnya adalah peserta diberi tugas secara berkelompok untuk membuat konten sederhana dan akan diupload ke youtube.
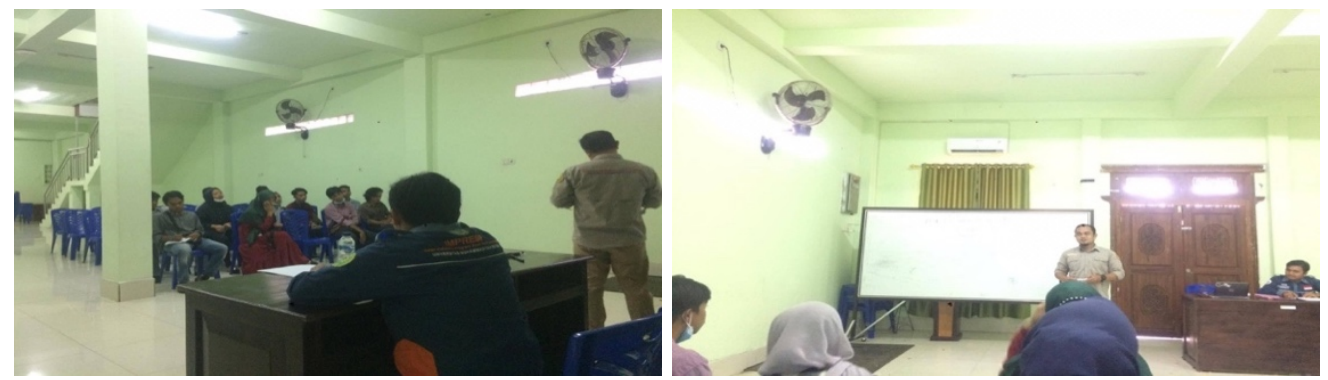

Sumber : Hasil Pelaksanaan (2021)

Gambar 5. Workshop Pengenalan Digital Marketing dan Pembuatan Konten Sederhana untuk Produk Usaha

Penekanan yang disampaikan pada workshop ini adalah bahwa peluang besar wirausaha saat ini yakni dengan adanya fasilitas internet, sehingga konektivitas penjualan 
usaha tidak terbatas ruang dan waktu. Dengan sangat kooperatif, peserta workshop saling memberi penguatan pada cara-cara mereka masing-masing dalam memasarkan produknya. Bahkan beberapa dari peserta memiliki kemampuan dalam melakukan pengambilan video dan editing, sedang yang masih menjadi kendala dari peserta ini adalah kemampuan membangun narasi yang dapat menghubungkan produk usaha mereka kepada konsumen.

Selanjutnya pelatihan dalam workshop digital marketing ini dilakukan melalui penugasan kelompok kewirausahaan memprioritaskan pada pembentukan perilaku seseorang agar menjadi lebih kuat dan berani dalam menghadapi tantangan dan memanfaatkan peluang dengan berbagai risiko yang dihadapi. Pelatihan pembuatan konten digital marketing diharapkan agar produk mahasiswa agar dapat berkembang meski saat ini tengah diperhadapkan oleh pandemi covid 19. Selain itu, pelatihan ini ditujukan untuk membangun ide-ide kreatif untuk menghadapi resiko-resiko seperti saat ini misalnya resiko finansial, psikis serta resiko sosial yang menyertainya.

Tahap selanjutnya pada pelatihan digital marketing ini adalah membuat konten marketing sederhana dan akan di upload ke youtube. Karena proses untuk ini membutuhkan waktu, maka peserta diberi waktu selama 2 minggu untuk membuat konten dan diserahkan kepada mitra pengabdian ini yakni pengurus IMPRESIP Fisip UM Buton. Adapun konten marketing sederhana yang telah dihasilkan pada pelatihan ini dapat diamati pada Gambar 6.

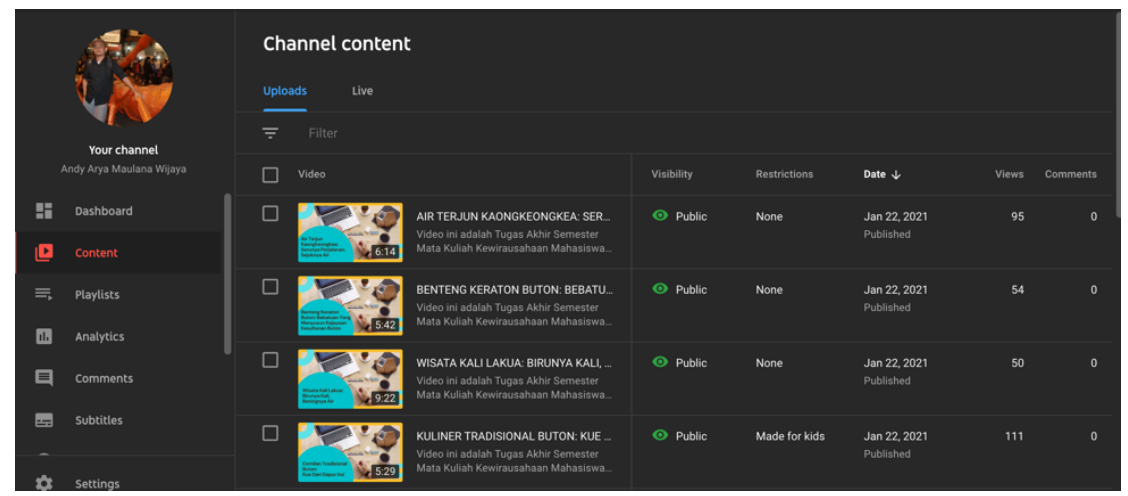

Sumber : Hasil Pelaksanaan (2021)

Gambar 6. Hasil Postingan Tugas Konten Marketing Peserta

Setelah peserta menggunggah laporan akhir berupa konten youtubenya, maka peserta akan diberikan sertifikat dan stiker bahwa telah menyelesaikan seluruh tahapan pelatihan digital marketing. Melalui proses ini diharapkan peserta memiliki keterampilan dan kompetensi untuk membangun branding produk mereka, serta mampu memberikan ketertarikan konsumen mereka terhadap produk usahanya. Bahwa kondisi pandemi covid 19 seperti saat ini, diperlukan adanya inovasi melalui ide kreatif untuk tetap bertahan dan salah satu solusinya adalah melalui kompetensi digital marketing.

\section{KESIMPULAN DAN REKOMENDASI}

Hasil kegiatan Pelatihan ini berjalan dengan lancar. Peserta mahasiswa terlihat antusias mengikuti materi dan pelatihan yang disampaikan, penugasan untuk membuat konten marketing sederhana diselesaikan sesuai jadwal, yakni dari 18 peserta yang dibagi menjadi 4 kelompok telah mengupload video marketing sederhana pada jadwal yang ditetapkan. Dari respon quiosioner akhir saat menggunggah video, didapati bahwa dengan praktek pembuatan konten dan penggunaan sosial media memberikan kemudahan peserta dalam mempromosikan produknya. Diharapkan dalam kegiatan pelatihan ini peserta mahasiswa mendapatkan ilmu pengetahuan baru, sehingga bisa dimaksimalkan potensi diri dengan berfikir inovatif dan kreatif dalam menghadapi pandemi covid 19 yang belum tahu kapan selesai ini. 


\section{DAFTAR PUSTAKA}

Adi, M., Nalendra, S., Husna, A., Visual, D. K., Informasi, F. T., Informasi, S., Informasi, F. T., Mada, G., Vitka, K., \& Tiban, C. (2021). WORKSHOP DESAIN PEMASARAN DIGITAL MELALUI APLIKASI CANVA DAN MOBILE PHOTOGRAPHY KEPADA PELAKU UMKM FOOD \& BEVERAGE DI TIBAN CENTER BATAM. Jurnal Sains Teknologi Dalam Pemberdayaan Masyarakat (JSTPM), 2(1), 17-24.

Azizah, N. (2019). Pelatihan Pemberdayaan Istri Nelayan Melalui Pelatihan Digital Marketing Strategy (DMS) Darah Biru. Dinamisia: Jurnal Pengabdian Kepada Masyarakat, 3(1), 131-141. https://doi.org/10.31849/dinamisia.v3i1.2675

Hanief, S., Januhari, N. N. U., \& Asmara, A. A. R. (2020). Pelatihan Digital Marketing Memanfaatkan Sosial Media dan Marketplace pada Usaha Dekorasi dan Catering Pernikahan. Widyabhakti, 2(3), 146-156.

Pranadji, T. (2016). Penguatan Modal Sosial Untuk Pemberdayaan Masyarakat Pedesaan Dalam Pengelolaan Agroekosistem Lahan Kering Studi Kasus di Desa-desa (Hulu DAS) Ex. Jurnal Agro Ekonomi, 24(2), 178-206.

Pranoto, P., Jasmani, J., \& Marayasa, I. N. (2019). PELATIHAN DIGITAL MARKETING UNTUK PENINGKATAN PEREKONOMIAN ANGGOTA KARANG TARUNA AL BARKAH DI KAMPUNG CICAYUR - TANGERANG. Jurnal Pengabdian Dharma Laksana. https://doi.org/10.32493/j.pdl.v1i2.2425

Purwana, D., Rahmi, R., \& Aditya, S. (2017). Pemanfaatan Digital Marketing Bagi Usaha Mikro, Kecil, Dan Menengah (UMKM) Di Kelurahan Malaka Sari, Duren Sawit. Jurnal Pemberdayaan Masyarakat Madani (JPMM), 1(1), 1-17. https://doi.org/10.21009/jpmm.001.1.01

Wijoyo, H., Ariyanto, A., Sunarsi, D., \& Faisal Akbar, M. (2020). Pelatihan Pembuatan Konten Digital Marketing Dalam Meningkatkan Kompetensi Mahasiswa. Ikra-Ith Abdimas, 3(3), 169-175.

Yusmedi Nurfaizal, \& Toni Anwar. (2019). Manajemen Usaha dan Pelatihan Digital Marketing UMKM pada KUB Batik Pringmas Desa Papringan Banyumas. JPMB: Jurnal Pemberdayaan Masyarakat Berkarakter, 2(2), 146-154. https://doi.org/10.36765/jpmb.v2i2.9 